\title{
Regional Nationalism and Soviet Anxieties during the Great Terror in Ukraine: The Case of Mykhailo Bykovets'
}

\author{
Olga Bertelsen \\ Columbia University
}

\begin{abstract}
This study examines Soviet nationalities policies and the elimination of Ukrainian intellectuals during the Great Terror in Ukraine by exploring the individual history of the Ukrainian literary figure Mykhailo Bykovets', one of the founders of the literary association "Pluh" (Plough) and one of the initiators of the Literary Discussion that emerged in the mid-twenties. The research explores the modus operandi of a key Soviet institution, the GPU/NKVD, and its proactive methods of the de-nationalization of Ukrainian society. Bykovets's criminal case seems to be axiomatic of the Great Terror, exhibiting common patterns of the secret organs' procedural and investigative tactics. Through an analysis of Bykovets's archival file, and the themes and questions that were central to the investigation of Bykovets's "crimes," the study illuminates the persistent national vector of repression against the representatives of the Ukrainian intelligentsia during the Great Terror.
\end{abstract}

Keywords: The Great Terror, Secret Police, Kharkiv, Ukrainian Intellectuals, Mykhailo Bykovets'

$\mathrm{V}$ ery little has been written in the West about the Great Terror (19361938) in Kharkiv, the first capital of the Ukrainian Soviet Socialist Republic, and the elimination of the Ukrainian intellectual elite there during this period of the Stalin era. Scholarly and memoir literature concentrates mostly on the early thirties and the state's brutal treatment of the intelligentsia who are remembered by the subsequent generations as the representatives of an "executed renaissance" (rozstriliane vidrodzhennia). The House of Writers (Budynok "Slovo"), a legendary building in Kharkiv built on the initiative of the Ukrainian intelligentsia, became an epicenter of human tragedies during the thirties. Immediately after 1930 when prominent cultural figures moved into their new luxurious apartments, the atmosphere in the building became quite dismal. The secret police began to arrest its residents one by one. After a decade of repression, by the late thirties, approximately 90 percent of the building's residents were arrested, exiled and executed as Ukrainian nationalists and as members of various nationalist organizations (Bertelsen 6). The individual histories of those slov"iany (i.e., the residents of Budynok "Slovo") who were arrested during 
the Great Terror are still waiting to be told, but all of them were accused of being Ukrainian nationalists and members of various anti-Soviet, fascist, terrorist Ukrainian nationalist organizations. ${ }^{1}$

In this light, the case of the Ukrainian writer, teacher and the slov"ianyn Mykhailo Bykovets' is quite emblematic. He belonged to a cohort of Ukrainian youth whose work flourished in the 1920s, and he was one of the founders and active members of the literary association "Pluh" (Plough), which emerged in Kharkiv in 1922, uniting peasant writers. Bykovets' published many of his works in the journal Pluzhanyn, edited by Pluh's founder Serhii Pylypenko. Bykovets' is also considered one of the initiators of the Literary Discussion in the mid-twenties, i.e., the polemics among Kharkiv writers that went beyond literary issues, provoking Stalin's fury. Importantly, during Bykovets's professional career as a writer and journalist, he amassed a considerable private archive which included a manuscript of a dictionary containing biographical and bibliographical information about the most prominent figures of Ukrainian culture, and a unique catalogue of cultural figures that spanned several centuries. The manuscript has never been published. The catalogue likely disappeared in the cellars of the NKVD after Bykovets's arrest.

Although an analysis of Bykovets's literary work lies beyond the scope of this essay, it is noteworthy that his colleagues never spoke of him as a talented writer. Some even identified Bykovets' as a sycophant, and treated him as Pylypenko's personal secretary and a promoter of Pylypenko's articles (Sokil 88; Kryzhanivs'kyi 128). Perhaps, precisely for this reason, literary critics and historians were reluctant to explore Bykovets's creative art and individual history. His contribution to Ukrainian literature and culture still remains in the shadow of rich historiography and literary studies about other slov"iany such as Mykola Khvyl'ovyi, Mykola Kulish, Mykhail' Semenko, Ivan Dniprovs'kyi and many others. Nevertheless, as an individual who took an active part in Ukrainian cultural construction in the 1920s and as a person who fell victim to Stalin's terror, Bykovets' deserves our attention from both historical and human perspectives.

\footnotetext{
${ }^{1}$ Among them were Mykhail' (Mykhailo) Semenko (HDA SBU, f. 6, spr. $44961 \mathrm{fp}$, ark. 2, 5); Ivan Kulyk (TsDAHOU, f. 263, op. 1, spr. 37630, t. 1, ark. 173-73zv.; HDA SBU, f. 6, spr. 44961 fp, ark. 159); Liutsiana Piontek (HDA SBU, f. 6, spr. 37631 fp, ark. 5153); Ievhen Kas'ianenko (AU SBUKhO, spr. 016309, ark. 100), Maik Iohansen (AU SBUKh0, spr. 015614, ark. 89-91); Volodymyr Koriak (HDA SBU, f. 6, spr. 36546 fp, t. 11, ark. 72-73, 81, 84); Antin Dykyi (AU SBUKh0, spr. 016310, t. 1, ark. 67-69); Ivan Kyrylenko (HDA SBU, f. 6, spr. 41465 fp, ark. 90zv-92); Hryhorii Kotsiuba (AU SBUKhO, spr. 014317, t. 2, ark. 396-400); Volodymyr Dukin (AU SBUKhO, spr. 013200, ark. 24-27; 40-42), and others.
} 
Moreover, Ihor Mykhailyn has suggested that among the slov"iany, there were no mediocre or trifling people. ${ }^{2} \mathrm{He}$ is convinced that just belonging to the "guild" of the slov"iany guaranteed a certain artistic and intellectual quality. Their creative art should be studied and popularized as Ukraine's national and intellectual property. Earlier, Mykhailo Drai-Khmara had argued that "minor writers more emphatically illuminate the life of their time than the so-called dignitaries. Simply because they are like lights brightening this life all around them" (qtd. in Shepeliuk 474). Possibly, Bykovets' might be identified as a minor writer who worked during the so-called Red Renaissance, but his individual history and the direction in which his creative work took him make it possible to observe significant patterns of the Stalinist era. Their synthetic analysis deepens our understanding about the Soviet regime, and the methods of operation of its key institution-the GPU/NKVD.

This research concentrates on the elimination of the Kharkiv literati, and the destruction and loss of literary artifacts, Ukraine's national heritage, during the Great Terror (1936-1938). Through an analysis of Bykovets's criminal file, and the themes and questions that were central to the investigation of Bykovets's "crimes," the study illuminates the persistent national vector of accusations against the representatives of the Ukrainian intelligentsia during the Great Terror. This focus is revealed by examining Bykovets's experiences in the cultural and political atmosphere of the 1920s and the 1930s.

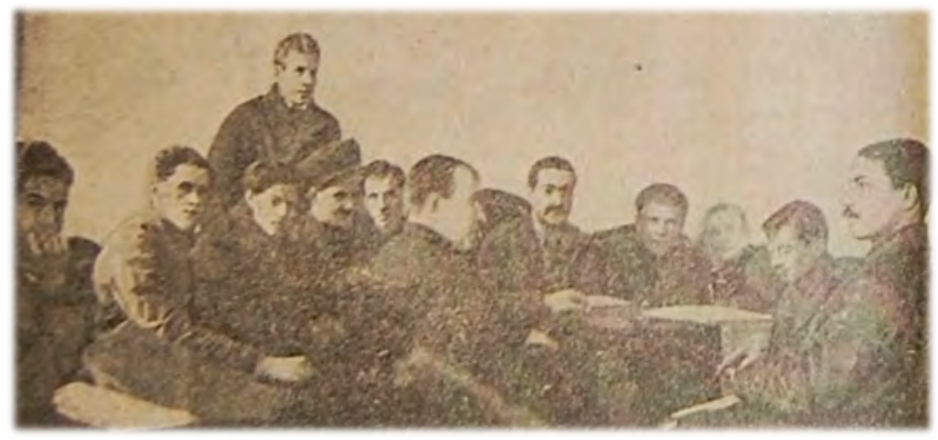

Fig. 1. A meeting of "Pluh" in 1924. From left to right: A. Hak, P. Vol'khovyi, P. Usenko, D. Bedzyk (standing), H. Epik, P. Panch, M. Lebid', S. Pylypenko, I. Kyrylenko, I. Koval'chuk, M. Bykovets'. Courtesy of the Korolenko State Scientific Library (Kharkiv). Source: Pluzhanyn 3 (1926): 20.

2 I am grateful to the Ukrainian philologist and professor of the Karazin State University, Ihor Mykhailyn, for his careful reading of earlier drafts of this text and for his thoughtful suggestions. 


\section{The Promising 1920s: Literature, Politics, Challenges}

Bykovets' was born on 3 September 1894 in the village Shershneva Balka (Zinkivs'kyi county of Poltava oblast) into the family of a doctor's assistant (P"iadyk 328). According to questionnaires Bykovets' completed for various agencies, his mother was a peasant (khliborobka) (TsDAVOU, 166/12/542). In May 1917, he finished eight years of study at the Myrhorod gymnasium. Amid the context of almost total illiteracy in the countryside, Bykovets's education was equivalent to a university degree which allowed him to teach. He began his career as a teacher at the Chernihiv pedagogical institute, but at the time of the turmoil under Denikin he found a job in a cooperative. For two years from 1918 to 1920 he worked as an inspector of the Culture and Enlightenment Department in the Union of Consumers' Associations in Myrhorod. But nostalgic for Poltava, Bykovets' returned home where he was hired as a member of the Collegium of the Department of People's Education in Zinkivs'kyi county (Marochko and Götz 69).

Bykovets' discovered himself as a poet, and from 1918 he began publishing his poems in various Ukrainian periodicals, including the journal Chervoni kvity ("Red Flowers") (Chervoni kvity 35). His education and literary gift did not go unnoticed. The Soviet leadership of the hubernia Department of People's Education in Poltava recruited Bykovets' for the post of inspector in the sub-department of Social Upbringing (hubsotsvykh). ${ }^{3}$ From 1921 to 1923, due to his organizational talents, he was promoted to the deputy head of hubsotsvykh, but he did not abandon his literary passion. Simultaneously, he edited the journal Novymy stezhkamy ("New Pathways").

In 1923 Bykovets' was transferred to the Department of Child Protection which functioned under the umbrella of the People's Commissariat of Enlightenment in Kharkiv. From July 1924 to January 1925 he worked as a chief inspector of this department, but as Bykovets' noted in his questionnaire for the Commissariat, his calling was teaching. He identified Ukrainian history, language, and journalism as his primary interests (Marochko and Götz 70). Kharkiv, however, presented new opportunities for Bykovets'. Its artistic and bohemian environment became a fertile ground in which he could finally fully apply his literary skills and test his editing abilities. He joined "Pluh" and, considering his previous teaching and literary experience, Pylypenko appointed him as head of the section of children's literature.

For quite some time, his career as a Soviet bureaucrat ran parallel with his literary activities. He became acquainted with writers, actors, artists, and the local party and GPU bosses. Interestingly, in October 1924, as a

\footnotetext{
3 On the history of Soviet social upbringing in Ukraine, see Arnautov 3-17.
} 
government official, Bykovets' was among the delegates to the First AllUkrainian Congress for Members of the Children Aid Commissions. There he met influential figures such as Shums'kyi, Zatons'kyi, Riappo, Ozers'kyi, Dukhno, Skrypnyk, and Balyts'kyi who were invited to the Congress as guests (Marochko and Götz 191).

Did Bykovets' ever used his powerful acquaintances to delay his demise in the bacchanalia of terror in the early thirties when the majority of the Kharkiv intelligentsia were imprisoned, exiled, and executed as members of various Ukrainian nationalist organizations? Was it accidental that Bykovets' was arrested only in 1937, at the peak of the Great Terror, one of the last slov"iany and active participants of the Literary Discussion that infuriated Stalin? Why did not Balyts'kyi arrest Bykovets' in the early thirties, together with Pylypenko, his chief and colleague at "Pluh"?4 Answering these questions might help explain the local dynamics and specificity of the early repression of the intelligentsia, and the Great Terror in Ukraine. Oleg V. Khlevniuk has aptly noted that in 1937-1938 the center controlled the operations against "anti-Soviet elements" and nationalities; we should not, however, reject "elemental factors," personal friendships, alliances, and "local initiative," which played a role in shaping the terror (Khlevniuk 185).

Bykovets' was arrested as a Ukrainian nationalist and a member of an anti-Soviet nationalist organization in August 1937. As several authors have argued, "bourgeois nationalism" was a common accusation hurled against people arrested in the Soviet republics during the Great Terror (Conquest 1969, 1990; Kuromiya 124; Weiss 23). The NKVD arrested Bykovets' a month after Balyts'kyi was neutralized by his own agency as the organizer of a "military-fascist conspiracy" in the NKVD. ${ }^{5}$ An irregularity such as Bykovets's belated arrest might simply be explained by the chaotic and disorderly nature of the Great Terror. In retrospect, the almost synchronic arrests of Bykovets' and Balyts'kyi might be purely coincidental. What is important here is that the theme of relations among the Ukrainian intellectual elite, party, and GPU/NKVD bosses still awaits a fundamental and thorough investigation for a better understanding of patterns of terror against Ukrainian intellectuals. Archival documents recently discovered in the former KGB archives in Ukraine, and scholarship, such as Iaryna Tsymbal's work on VAPLITE, suggest that some Ukrainian intellectuals in Kharkiv ingratiated themselves with the chekists (GPU/NKVD agents). Similarly, it

4 From March 1924 Vsevolod Balyts'kyi held two posts: head of the GPU and Commissar of Internal Affairs of Ukraine (Shapoval, Prystaiko, and Zolotar'ov 26).

5 Balyts'kyi was arrested on 7 July 1937 and, according to the official data, he was executed on 27 November 1937 (Shapoval, Prystayko, and Zolotar'ov 68-69, 73; Shapoval and Zolotar'ov 322-60). 
was flattering for some party and secret police bosses to stand close to the Ukrainian intellectual elite (AU SBUKhO spr. 06847; Tsymbal 137-39). The client-patron relations developed in the process of their "friendships," and the interactions among them might have determined the sequential screening for repression and might have shaped its final local dynamics.

Borys Lysyts'kyi, Vsevolod Balyts'kyi, and many other NKVD officials spent a great deal of time partying with the Ukrainian literati and people of culture. If for Lysyts'kyi these encounters were of a hedonistic nature, Balyts'kyi used his time productively, studying the famous Kharkovites in terms of their loyalty to the regime and their ideological flexibility. For instance, it is no secret that Khvyl'ovyi and Balyts'kyi regularly communicated before Mykhailo Ialovyi's (pseudonym of Iulian Shpol) arrest. Various relationships, often uneasy, developed between Balyts'kyi and the Kharkiv party elite-Skrypnyk, Kvirinh, Kaganovich, Shums'kyi, Kosior, Postyshev, Liubchenko, and other party officials. Another of Balyts'kyi's habits was to personally supervise preliminary investigations. He "chatted" with several writers and party leaders, as they were confined in Sovnarkomivs'ka Street, the GPU/NKVD headquarters in Kharkiv, and in the Luk"ianivs'ka prison in Kyiv. Balyts'kyi's name was recorded in several interrogation protocols of members of various so-called Ukrainian nationalist organizations, starting with the SVU (Union of Liberation of Ukraine) case fabricated by the GPU in 1929-1930.6 Balyts'kyi apparently considered it his professional duty to observe the elite. Whether he played a role in Bykovets's fate remains unknown.

In the 1920s, Bykovets' socialized with many Kharkiv literati who inspired his creativity. He plunged himself into journalism. Following literary traditions and fashion, he began to publish his work under various pseudonyms, such as Ashym, B-ets M., M. B., Marusyk Mykh., Mykh. Byk., Mykh. Myk., Motoroshnyi, Nevira Kharyton, Khar'ko Nevira, Olivets', and others (P"iadyk 328). Bykovets' collected an impressive library, and read extensively: he was eager to acquire knowledge about Ukrainian culture, which was not taught in secondary and high schools. Curiously, unlike many of his fellow pluzhany (members of "Pluh"), he was not a party member, but he was an active participant in the cultural, political and social life of Kharkiv.

Pylypenko asked Bykovets' to be secretary of the journal Pluzhanyn. A person of enormous energy and enthusiasm, Bykovets' agreed, but his responsibilities went far beyond secretarial work. He used his time very productively, and was able to simultaneously chair a meeting, to edit an article, to sort out the journal's correspondence, and to maintain a

6 Balyts'kyi interrogated Serhii Iefremov on 23 December 1929. See HDA SBU f. 67098fp, t. 12, ark. 230-31 (the SVU case); and Snehir'ov 115. 
meaningful conversation with visitors. The editorial room was always crowded and bustling, where Bykovets' answered the authors' questions and distributed guidelines for organizing the next issue of the journal. The writer Ivan Senchenko has argued that Bykovets' was the real editor of Pluzhanyn and "more than half of the first issues... Mykhailo Bykovets' wrote himself under various pseudonyms" (Senchenko 1990). As noted earlier, his colleagues never considered Bykovets' a brilliant writer largely because of his provincial origin and pragmatism, which, in their view, constrained his poetic talent. Nevertheless, they gave him credit for his fantastic organizational skills and unquestionable competence, and they respected him for being an honest, sincere, down to earth, and industrious individual (Senchenko 1990).

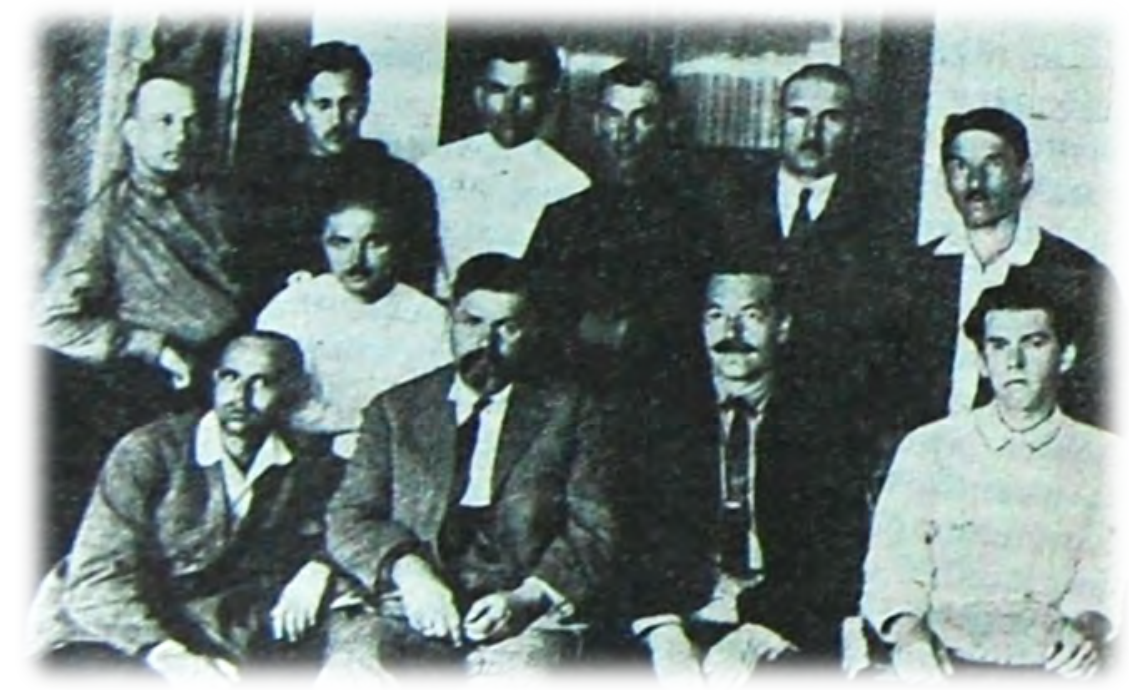

Fig. 2. A group of writers together with Professor V. Simovych (Prague) during his stay in Kharkiv at the conference dedicated to Ukrainian orthography. Sitting from left to right: I. Mykytenko, A. Paniv, V. Simovych, S. Pylypenko, P. Tychyna. Standing: M. Lebid', M. Samus', V. Mynko, O. Demchuk, A. Hak, M. Bykovets'. Courtesy of the Korolenko State Scientific Library (Kharkiv). Source: Pluzhanyn 11-12 (1927): 54.

Indeed, he was a person who was wearing many hats, and his everyday schedule was rather hectic. As the chief inspector of the capital's office that dealt with children, Bykovets' made important decisions in assisting the Gorky colony for homeless and delinquent children and teenagers headed by Antin Makarenko. Mykhailo participated in numerous meetings on the city, republican and state levels where the government discussed ways to protect 
the legal rights of minors, to help starving children and to improve their material and cultural well-being. Bykovets' published many articles in scholarly pedagogical and educational journals about the role of literature in children's education and about how to improve the work of educational institutions and schools for children (Marochko and Götz 71, 72). However, he gravitated toward literary criticism, and subsequently his articles reflecting cultural construction in Ukraine appeared on the pages of literary journals and magazines.

March 1925 marked a transitional period in Bykovets's life. He was hired by the State Publishing House of Ukraine (DVU) as an editor to chair the department of books for children. Finally, Mykhailo's professional responsibilities included creative thinking and writing, skills that were very much appreciated by the DVU. He met with and befriended those who had already gained fame as Ukrainian poets and writers. Among them were Vasyl' Blakytnyi, Mykola Khvyl'ovyi, Volodymyr Sosiura, and many others. During the mid-twenties, at the peak of the Ukrainization campaign, Bykovets' published serious essays on the history of Ukrainian literature and culture, journalistic inquiries, and reviews of books and articles written by Taras Shevchenko, Mykhailo Kotsiubyns'kyi, Ostap Vyshnia, and other famous Ukrainian writers.

In the same year, the Literary Discussion emerged and continued until 1928 (Luckyj 1990; Shkandrij 1992). Scholars of Ukrainian literature disagree about who exactly initiated it. The most celebrated American linguist of Ukrainian origin and a specialist in Ukrainian literature, Iurii Shevel'ov, has posited that Bykovets's and Hryhorii Iakovenko's articles propelled the literary debates. They were quickly politicized and annoyed even Stalin himself who wrote an indignant letter to Kaganovich and to the members of the Ukrainian Politburo, denouncing the nationalism and separatism of Khvyl'ovyi and his associates (Stalin 152).

Bykovets' found himself among Khvyl'ovyi's opponents, and published an article "The Discussion on the Literary Front" (Shevel'ov 294). His main objective was to rebuff Khvyl'ovyi's attacks on "Pluh" (Marusyk 1925; Byk 1925; Nevira 1926; Sokil 88). At the peak of Khvyl'ovyi's political persecution, when the party forced him and his fellow VAPLITE members Oles' Dosvitnii and Mykhailo Ialovyi to write an openly repentant letter, which was published in the newspaper Visti-VUTSVK in December 1926, Bykovets' under the pen name Khar'ko Nevira wrote a scathing critique of Khvyl'ovyi's work and position (Nevira 1927, 23; Shapoval 18). Bykovets' endorsed the views of the Russian critic Mykhailo Bekker, who diminished Khvyl'ovyi's artistic talent and condemned his ideological perversion. Bykovets' belittled Khvyl'ovyi's "boredom, disillusionment, disbelief in his own abilities, and lack of a clear artistic vision (and all this-during such a 
heroic and beautifully creative era of our times!)" (Nevira 1927, 23). However, several decades later, defending Khvyl'ovyi, Shevel'ov poured his wrath not on Bykovets' but on Iakovenko who provoked Khvyl'ovyi's response in a boorish and offensive manner (see Iakovenko 1925). Shevel'ov identified Iakovenko as an "insignificant" (desiatyriadnyi) and "fairly longforgotten" writer (Shevel'ov 294).

In the vortex of the Literary Discussion, and amidst the burdens of editing and publishing, Bykovets', as a reporter, also made time to travel extensively to the sites where Ukrainian history was forged. In May 1927, together with a colleague, he went to Kaniv to visit Taras Shevchenko's grave and to see the Kobzar's new monument, which was erected in 1923 on the spot of the historical cross that was erected there during Shevchenko's funeral (Savchenko 1930). In an article written about this trip, Bykovets' lamented that the attitude of the People's Commissariat of Enlightenment toward cultural monuments was careless, and the monument to Shevchenko was made without proper affection and taste. He maintained that the only joys in this place were the magnificent nature, the picturesque banks of the Dnipro River, and an old man named Ivan, an interesting person who lived there alone, tending the flowerbeds on Shevchenko's grave for almost half a century (Bykovets' 1927, 32). A boat took the writers home the next morning.

Bykovets' and his friend spent the night at the wharf, ruminating about the place, Shevchenko, and the old man Ivan. Bykovets's friend meditatively noted that it would be so wonderful to stay there forever: "It is so quiet here; there is no street noise, and all our worries disappeared." Bykovets' replied:

Hmmm, it is indeed so! But how long would we able to tolerate it, living here in this tranquility? Shevchenko also fantasized about residing here and asked his brother Vartolomei to buy him a house in Kaniv, but he would unlikely be glued to this place! Imagine the winter here-all is covered with snow, it should be windy and cold here! It is nice just to rest here a bit. Active life and struggle-that's what always attracts people. Look what is here-a grave, tranquility, and memories. No, one cannot live here for a long time! Maybe, only this old man Ivan can-he's been sitting here for 45 years, but is he a participant in life?! Everything passes him by... (Bykovets' 1927, 34).

In the morning, the boat took them home, but Bykovets' continued to think about this place of memories, about the boat that was bringing them back to a "real and cheerful life and a vigorous struggle, about which Shevchenko could have only dreamed, and could not have imagined" (Bykovets' 1927, 34). Tragically, being an active "participant in life" in 1927, Bykovets' could not envision the future either, the time when he would be arrested as a counterrevolutionary, nationalist, and foreign spy. 


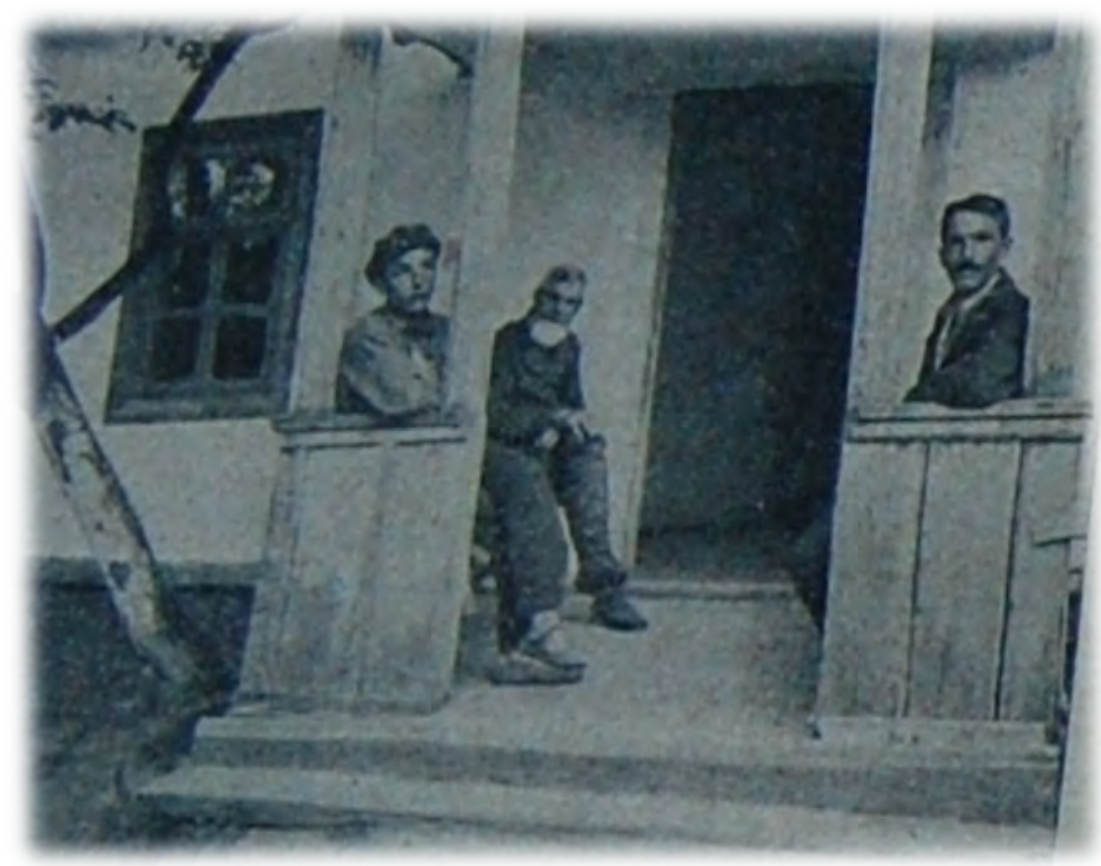

Fig. 3. On the porch of the old man Ivan's little house near Shevchenko's grave in Kaniv. From left to right: Bykovets's colleague, the old man Ivan, Bykovets'. Courtesy of the Korolenko State Scientific Library. Source: Pluzhanyn 5 (1927): 32.

In 1927 Bykovets' was invited to work for the Ukrainian peasant newspaper Radians'ke selo ("Soviet Village") (AU SBUKhO, spr. 035463, ark. 24). As a member of the editorial board, he corresponded with many famous Ukrainian writers. The Ukrainian writer and academician of the Ukrainian Academy of Sciences Serhii Iefremov was among them. The 1928 publication Selians'kyi Kalendar ("Village Calendar"), which appeared in the Publishing House Radians'ke selo, cost Bykovets' his post (Marchenko 1928). The calendar contained biographical information about the "disgraced" academicians Mykhailo Hrushevs'kyi and Serhii Iefremov. ${ }^{7}$ Andrii Khvylia, chief ideologue of culture in Ukraine, fired Bykovets' for nationalist deviation

\footnotetext{
7 The calendar represents the Bykovets's titanic work of collecting information about the structure of the political system and government in the Soviet Union and the Ukrainian SSR, cultural construction in Ukraine, state legislation regulations, statistics on social and economic life of the USSR and UkrSSR. The calendar also contains helpful suggestions for farmers and gardeners, as well as various maps of the USSR and UkrSSR.
} 
and ideological short-sightedness. Iefremov wrote in his diary: "Before the summer, in Radians'ke selo M. Bykovets' published Hrushevs'kyi's and my biographies. Today [7 November 1928] I learned that he paid for this: Khvylia who is in charge of the printed word fired the poor boy..." (Iefremov 603, 614; Marochko and Götz 73).8 In 1930, Iefremov himself was tried in court for charges fabricated by the GPU in what became known as the SVU trial. Bykovets' lived in trepidation for another seven years, waiting for a visit from GPU/NKVD agents.

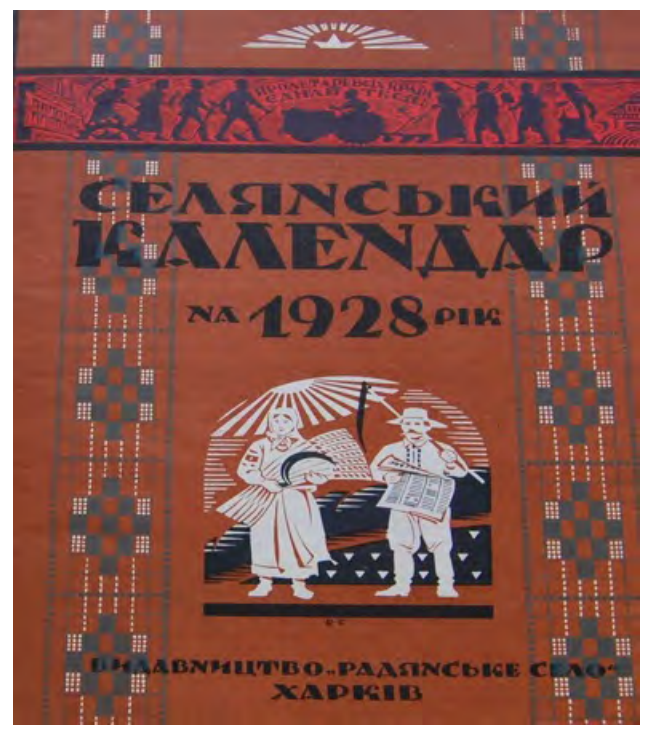

Fig. 4. The cover page of the original publication of Selians'kyi Kalendar. Courtesy of the Korolenko State Scientific Library.

This was the time when the party vigorously fought Ukrainian nationalism and nationalist deviations. By late 1928, many Ukrainian writers realized that the prospects of Ukrainization had become obscure and murky. Whether Bykovets' was among them is unclear. He might have been a true Communist believer, but without a membership card in his pocket. Apparently, he felt quite secure because precisely during this time he

\footnotetext{
${ }^{8}$ Later in 1931 Khvylia wrote a report to the TsK KP(b)U, in which he denounced national deviations of many famous Ukrainian writers (TsDAHOU, f. 1, op. 20, spr. 4190, ark. 1-33). For more details on Khvylia's attitude toward Iefremov, see TsDAHOU, f. 1, op. 20, spr. 4189, ark. 26).
} 
conceived a project that would be deemed legitimate and in tune with the party's nationalities policies to Ukrainianize the republic. Bykovets' moved forward with a manuscript of a dictionary on Ukrainian culture and its proponents (AU SBUKhO spr. 035463, ark. 26). His research for this manuscript served as a foundation for another project, an article entitled "On Ukrainian literature" which was published in Selians'kyi Kalendar. This essay analyzed works written by various Ukrainian writers, including Volodymyr Vynnychenko, who a few years earlier was declared an enemy of the people, and persona non grata in Ukraine. Vynnychenko was the only immigrant whose works were published in Soviet Ukraine until 1933, and for which he received honorariums. But in the late 1920s, the party leadership began to increasingly portray him as a nationalist and fascist. ${ }^{9}$ Bykovets' also published Vynnychenko's story "V ekonomii" and identified him as a prominent Ukrainian writer. In light of the Literary Discussion, Stalin's related attacks on Ukrainian writers and accusations of Ukrainian nationalism, Bykovets's actions might be characterized as a suicidal impulse. More optimistically, this behaviour was a result of his principled position, and even an example of civic courage. At the very least, his behavior seems to have been fairly irrational and might have played a role in his subsequent arrest. ${ }^{10}$

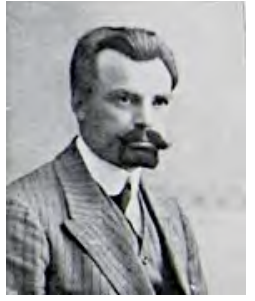

Fig. 5. Volodymyr Vynnychenko. Courtesy of TsDAMLIM of Ukraine (f. 271, op. 1, spr. 310, ark. 6).

\footnotetext{
${ }^{9}$ Volodymyr Vynnychenko was the first President of the Ukrainian Government (the Direktoriia) of the UNR in November 1918, and a Ukrainian writer. For a discussion about Vynnychenko's art and individual history, see Dziuba 299-302; Panchenko 294305; Hrechaniuk 68-72. See also Vynnychenko's open letter to the Soviet leadership and to Stalin which was characterized as a manifestation of Ukrainian nationalism and fascism (TsDAHOU, f. 1, op. 20, spr. 2258, ark. 1-24; f. 1, op. 20, spr. 6205).

10 Many scholars have written about the irrationality of human behavior as a psychological marker of a suppressed individual who lives under chronic stress and fear of being arrested, a phenomenon that complicates logical explanations of human behavior. Scholarship on subjectivities under Stalinism is quite extensive. See, for instance, Hellbeck 2009; Halfin 2003.
} 
It is equally difficult to say whether Bykovets's position, which was generally consistent with the party line, prevented the "ocean of blood" 11 from absorbing him earlier, together with his fellow slov"iany. Whatever the case, a few months before the SVU show trial, which in 1930 sentenced the first 45 and later thousands of representatives of the Ukrainian intelligentsia to forced labour in camps and some to death, in May 1929 Bykovets' submitted another calendar-dictionary for publication to the DVU, where he included biographies and bibliographical information about prominent Ukrainian cultural figures in the areas of literature, art, film, theater, and music (Chervonyi shliakh 1929: 253). He did not seem to sense his vulnerability even though he was a member of the very stratum of Ukrainian society that was labeled as "bourgeois nationalists" and "nationalist deviationists."

\section{THE STORMY THIRTIES IN BUdYNOK “SLOVo"}

Despite the rather tense political and economic situation in Kharkiv in the late 1920s and early 1930s, Bykovets's literary career advanced. In 19291930 he worked as a literary secretary for the magazine Sil's'kyi teatr ("Village Theatre") (AU SBUKhO spr. 035463, ark. 25). In 1930 he edited and published a collection of plays entitled Otak to teper ("So it is now") (Bykovets' 1930). A politically correct publication, it was designed to inspire enthusiasm about the collectivization campaign recently announced by the government. He also produced translations, a practice adopted as a source of additional income for Kharkiv writers. ${ }^{12}$ The financial position of many Kharkiv literati was deplorable. They systematically starved. In the twenties, thanks to popular Ukrainization, translations of foreign authors into Ukrainian saturated the book market.

Many works written by European, Russian, classical, and contemporary writers were translated into Ukrainian and were published in Kharkiv for the first time. All periodicals in Kharkiv eagerly solicited translated works. Interestingly, translated literature (from all languages) constituted $31 \%$ of all printed literary production in 1923. On average, over the decade from 1917 to 1927 translations amounted to $15-20 \%$ of published materials (Hodkevych 59). ${ }^{13}$ Translations became a means of survival for many

11 This metaphor was borrowed from the famous Russian dissident Iurii Orlov's memoirs (Orlov 14).

12 Bykovets' translated the works of Maxim Gorky and Mikhas' Zarets'kyi into Ukrainian (Dzeverina 162).

${ }^{13}$ Scholarly articles about the art of translation began to appear during this time. See, for instance, Zerov 133-46. 
writers. By 1933 the state subsidies for Ukrainian periodicals were substantially reduced, as well as their circulation, and the opportunity to earn additional monies gradually faded away.

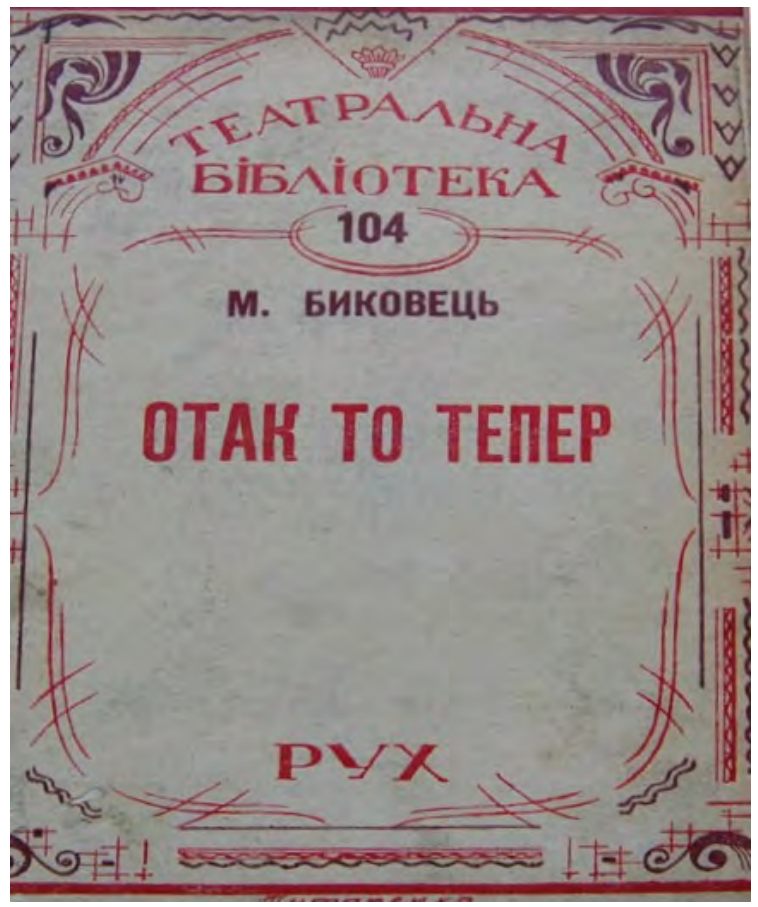

Fig. 6. Cover of the original publication of Bykovets's Otak to teper. Courtesy of the Korolenko State Scientific Library.

Beyond translations and the collection of plays, Bykovets' continued his research on Ukrainian culture. Vasyl' Sokil and Ivan Senchenko (both were teachers and writers) left the most comprehensive recollections about Bykovets' as a researcher and as a person. They were Bykovets's friends and neighbors in Budynok "Slovo." His catalogue (kartoteka) included 8000 cards with bio-bibliographical information about Ukrainian political and cultural figures, and about historical and cultural events in Ukraine. The catalogue disappeared after Bykovets's arrest in 1937. According to Senchenko, after his arrest, his archive might have been thrown into the basement of Budynok "Slovo" (Senchenko 572). Yet, there is also another possibility. After Bykovets's arrest, NKVD operatives broke into his apartment, and his personal possessions, including his catalogue and manuscripts, ended up in 
the cellars of the secret police in Sovnarkomivs'ka Street. These materials could have served as a rich source of information for additional persecutions. Bykovets' moved to Budynok "Slovo" in 1930.14 Prior to 1930, he found shelter in a secondary school's guard room:

He [Bykovets'] had nothing to do with the school... this room had a separate entrance. How Mykhailo got this room is unknown. This was a special school which was subordinated directly to the Commissariat of Education. Children of many state officials studied there, and the school was considered exemplary in all respects. In the late twenties, the Commissar Mykola Skrypnyk himself supervised all affairs in this school. So perhaps Mykhailo once asked Mykola Oleksiiovych [Skrypnyk] to help him find housing. People's Commissars then were more democratic and more accessible to ordinary people than ministers are now (Sokil 84).

A few months before settling in Budynok "Slovo" Bykovets' and Sokil shared this room. The construction of "Slovo" was in progress, and in 1929 Bykovets' suggested that Sokil should join the cooperative "Slovo," so that they could split the payment and share a large three-room apartment there. In 1930 both moved into "Slovo," joining the community of famous residents, such as Leonid Chernov, Andrii Paniv, Oleksandr Kopylenko, Andrii Holovko, Mykola Khvyl'ovyi, Maik Iohansen, and Pavlo Tychyna (Sokil 84, 85).

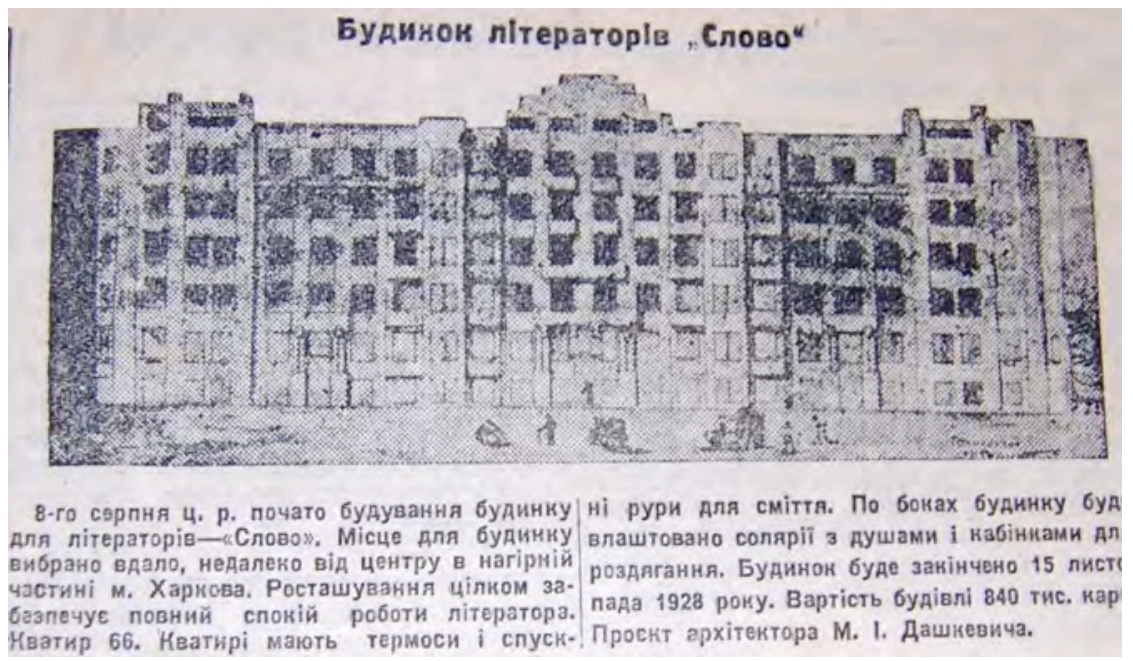

Fig. 7. News about the construction of Budynok "Slovo" in Vistsi VUTsVK, 29 September 1927. Courtesy of the Korolenko State Scientific Library.

${ }^{14}$ Construction was completed in late 1929 , and the writers celebrated the $1930 \mathrm{New}$ Year in their luxurious apartments. 
Sokil was impressed by a treasure Bykovets' had in his suitcases: a huge collection of hand-written cards. Bykovets' himself built bookshelves, from the floor to the ceiling, and filled them with the cards. The chronological boundaries of this rare collection covered several centuries. This was his life's work, and Mykhailo regularly added more cards to his rich collection. Sokil has claimed that back then no one, except him, knew about this unique collection and about the extensive research Bykovets' conducted that was neither commissioned nor sanctioned by the authorities (Sokil 88-89).

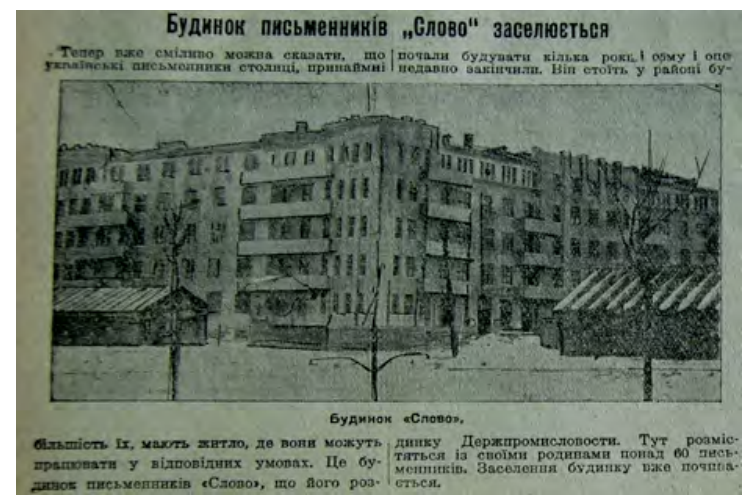

Fig. 8. Visti VUTsVK announced the completion of Budynok "Slovo's" construction, 25 December 1929. Courtesy of the Korolenko State Scientific Library.

In the depressing atmosphere of the party's campaign against Ukrainian nationalists, Bykovets' continued to work on a biographical dictionary entitled 400 Years, and in July 1931 he even signed a contract for its publication with the Publishing House "Ukrainian Soviet Encyclopedia" (URE) (Liashko 584-86). His research and catalogue served as the foundation for his manuscript. The most detailed information offered by Bykovets' was on contemporary Ukrainian writers, his colleagues and neighbors in Budynok "Slovo." But further relationships between him and the publisher remain unclear, as well as the fate of Bykovets's private archive. Likely, his project was frozen because by late 1933 the state manufactured the image of the URE as a "nationalistic" enterprise. Its activities were curtailed, and its leadership, Anton Bilen'kyi-Berezyns'kyi and Oleksandr Badan-Iavorenko, were arrested (Rubliov and Fel'baba; Borchuk 2015). According to his neighbors' memoirs, however, Bykovets' had been working on the bibliographical dictionary until his arrest. These efforts characterize Bykovets' as a persistent and thorough researcher, and a connoisseur of Ukrainian culture. 
Subsequently, Bykovets' invited another colleague, young writer and teacher Mykola Dukyn, who worked in the journal Pluh, to rent a room in his apartment. Thus, apartment 14 became rather populated, and less expensive for its residents. Natalka Dukyna, Dukyn's daughter, for whom Bykovets' was simply "Uncle Misha," recalled that the atmosphere in their apartment was very friendly and warm. Conversely, very soon it became quite depressing because of chronic arrests in the building which emptied many apartments. The Sokils and the Dukyns were able to acquire their own. In 1937, after Bykovets's arrest, Ivan Plakhtin, who from 1934 to 1941 chaired the primary party cell in the Kharkiv chapter of the Union of Writers, moved into his apartment. According to Dukyna, he played a significant role in the arrests of many slov"iany, quite possibly in Bykovets's arrest as well (Dukyna 68, 69, $74,359,528)$. After WWII and the first wave of rehabilitations in 1956, some writers returned to Kharkiv. To avoid difficult questions about his past, Plakhtin gathered his things and quickly moved to Kherson.

Senchenko and Volodymyr Kulish (son of the playwright Mykola Kulish) shed some light on Bykovets's private life, although their memories are somewhat inconsistent with one another. We have to take into consideration that Kulish was a child in the 1930s, so Senchenko's account about Bykovets's affairs of the heart inspires more confidence. According to Senchenko, Bykovets's private life was unhappy. His relationship with Oles' Dosvitnii's sister failed. Later, when Bykovets' was over thirty, he met a woman with whom he was in love when they were both young. She was a widow, and had a son. They started a family, and she moved with Bykovets' to his apartment in Budynok "Slovo." However, he did not get along with her son, and she left Bykovets'. He suffered greatly because he loved her very much. By the time of his arrest in 1937, he was single and had no family but his brother (Senchenko 1990).

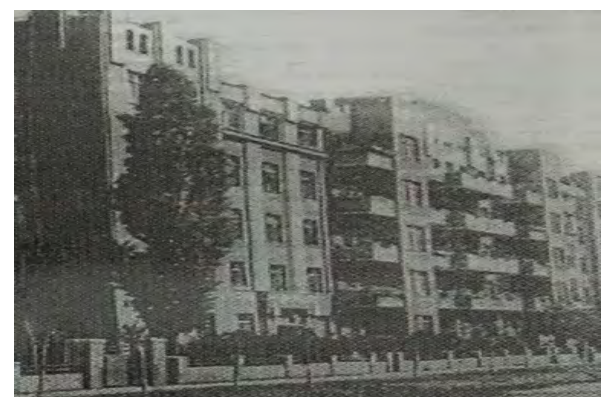

Fig. 9. Budynok "Slovo" in the 1930s. Courtesy of the Korolenko State Scientific Library. 
Little is known about Bykovets's professional life between 1933 and 1937. We do know that he became the director of the Litfond [Literary Fund] in the Kharkiv chapter of the Union of Writers. ${ }^{15}$ In the early 1930s, he witnessed the arrests of the majority of the slov"iany, and of his fellow members of "Pluh." His office of sotsvykh, as well as the entire Commissariat of Education, where he used to work, was cleansed of "national deviationists." How did Bykovets' react to the terror of mammoth proportions that had shaken Ukrainian institutions in general and the Budynok "Slovo" in particular? The answer to this question might be found in Bykovets's diaries and private notes, which disappeared together with his extensive private archive. Bykovets's operational file (papka-formuliar) that one day may be discovered in the Ukrainian archives might also shed light on his behaviour, views, habits, and mood. ${ }^{16}$

\section{BYKOVETS' UNDER ARREST: WHAT THE NKVD WANTED TO KNOW}

Bykovets' was arrested on 24 August 1937, when millions of the Ukrainian peasantry had been starved to death, when "nationalist deviation," such as khvyl'ovism, shumkism, and volobuievshchyna had been "conquered," and the majority of Ukrainian intellectuals were eliminated as members of various anti-Soviet nationalist organizations, including the UV0.17 These tragedies and Ukrainian society's reaction to them became a political and sociological test, telling the Kremlin about the inability of Ukrainians to resist the repression. The absence of any counterbalance to overpowering state violence and the ease with which the center removed Ukrainian intellectuals provoked further systematic repressions of the creative, scientific, educational, and technical elite. By 1933, the society in Ukraine began to exhibit signs of national, social, and cultural catastrophe (Marochko, and Götz 6,12). Those who were invited to conduct and promote Ukrainization

\footnotetext{
15 In July 1928 the Kharkiv writers' committee on financial and legal matters began to work on the creation of the local Literary Fund organization (Litfond), mimicking one founded in the RSFSR in order to help writers financially, especially young writers (Chervonyi shliakh, 7 [1928] 241). For more details about the Russian Litfond, see Literaturnomu fondu SSSR 125 let (1984).

16 As a rule, the GPU/NKVD invested substantial resources in surveillance of most representatives of the Ukrainian intelligentsia. Denunciations and reports by secret agents about a certain individual were compiled in a special operational file called papka-formuliar. For more details about these documents, see Shapoval 2009a; Danylenko 33; Vatulescu 36.

17 The UVO (Ukrainian Military Organization) was fabricated by the GPU. For a discussion, see Zolotar'ov 2007, 11, 42, 46, 201-06, 255; Shkandrij and Bertelsen 2013.
} 
were identified as Ukrainian nationalists and were isolated from society. They had to be replaced by more reliable and obedient functionaries. The "principle of total interchangeability" became predominant in all social arrangements (Zabuzhko 32).

Once the final victory over the nationalist deviations of intellectuals in Ukraine and the ideological perversions of Ukrainian party leaders had been declared, the center's rhetorical tactics changed during the Great Terror. The American historian Hiroaki Kuromiya has demonstrated that most criminal charges in 1937-38 in Ukraine were based on Articles 54-8 and 54-11 of the Criminal Code of the Ukrainian SSR (Kuromiya 2009). People were accused of "counter-revolution" and "anti-Soviet activities." They allegedly were agents of foreign intelligence services, but nevertheless were still accused of being members of nationalist organizations. Bykovets' was no exception. He was identified as a member of an anti-Soviet nationalist terrorist organization in Ukraine and as a foreign spy (AU SBUKhO, spr. 035463, ark. $1,78)$.

Bykovets's criminal case belongs to the so-called "conveyor" cases which were instantaneously fabricated during the Great Terror. ${ }^{18}$ NKVD operatives wasted neither paper nor time. During the previous years of terror, the procedures of arrest, search, and preliminary investigation were perfected by the GPU/NKVD, and to convict a person typically took from one to two months. In some cases, skillful "shock-workers" managed to prove the guilt of the accused within two or three weeks. The script and methods of interrogation were rehearsed in detail; routine confessions were sufficient, but not a mandatory condition for finalizing the case. To create an illusion of thorough investigative work, copies of other people's confessions and denunciations compromising the new victim and somewhat relevant to the case were sewn into the file of the accused. The file (sprava) became visually thicker on a daily basis, which served as evidence of the interrogator's persistence and effectiveness.

The pattern of Bykovets's criminal file is symptomatic of those created during the Great Terror. First, it is shamelessly thin. The investigators stopped pretending, and quit investigating. Apparently, for them it was no longer important to create an illusion of thorough work. This file exhibits haste and carelessness. Second, the minutes of interrogation indicate that they were written by a literate but linguistically unskillful and mediocre investigator, with questionable education and equally questionable knowledge of proper Russian or Ukrainian. This was typical. In fact, this description fits the education patterns of most NKVD operatives, including

18 For other cases, see archival files of Ukrainian writers mentioned in footnote 1. 
the NKVD leadership (Zolotar'ov 2009, 60-83). Yet what is not typical here is that there was no attempt whatsoever by Bykovets's interrogator to camouflage his poor language skills to make Bykovets's depositions appear authentic. The self-perception of NKVD officers' impunity seems to have been very well developed and solidified by 1937, and forgeries were a wellestablished practice among them. Usually, the accused were encouraged to write their own autobiography or to phrase their own confession to make them look authentic and believable, even if they were obtained through physical and mental torture. During the Great Terror, the pretense that the accused participated in writing their own self-incriminating confessions was for the most part dropped, and the obvious fabrication of confessions is apparent to anyone who reads Bykovets's "depositions," which are borderline illiterate and mediocre. Bykovets's signature placed on every page of his deposition does not make them more authentic.

An atypical act by NKVD operatives has to do with geography. Unlike the other slov"iany, Bykovets' was arrested not in Budynok "Slovo" but in the village of Bilyk (Kobeliats'kyi district of Poltava oblast), where he went for his vacation. On the banks of the Vorskla River, the writers had founded the House of Creativity (Budynok tvorchosti), and apparently, a trip to this picturesque place was a pleasant change for NKVD operatives. ${ }^{19}$ The night arrests of the slov"iany-as an intimidation tactic for those who waited for their turn-were no longer necessary. By 1937, Budynok "Slovo" had few writers left, and the building teemed with NKVD associates who hijacked the apartments after the arrest of their legitimate owners.

Importantly, Bykovets' was arrested without the prosecutor's sanction, even though the 19 August resolution of the Kharkiv Military District Prosecutor about his arrest had been written on a standard printed form of the Military Prosecutor's Office. The Prosecutor's printed name is absent from the document, and the signature cannot be deciphered (AU SBUKhO, spr. 035463, ark. 2). A summary of Bykovets's criminal case (ohliadova dovidka), discovered in the sectoral archive of the Security Service of Ukraine in Kyiv, sheds light on who ordered his arrest. The summary states that on 24 August 1937, a special telegram sent by the NKVD Administration in the Ukrainian SSR (Kyiv) to Kharkiv ordered Bykovets's arrest (HDA SBU, spr. 36546fp, t. 11, ark. 223). Considering the strict hierarchy and centralized

\footnotetext{
19 The Ukrainian writer Iurii Ianovs'kyi and the Hungarian writer and revolutionary Mate Zalka enjoyed the place tremendously; they fished there, and, perhaps, the initiative of creating a Budynok tvorchosti at this spot belonged to them. In 1982 in Kobeliaky the Museum of Literature and Art was founded, where approximately two thousand documents are located which are related to the stay in Kobeliaky of wellknown Ukrainian and Russian writers, among whom were also the slov"iany.
} 
nature of the secret police's injunctions and the fact that Bykovets' was arrested on the same day the telegram was issued, the initiative seems to have emanated from the Kyiv NKVD. Apparently, the 19 August resolution of the Kharkiv Military District Prosecutor was produced in haste, post factum, after Kharkiv received Kyiv's telegram. The local initiative to arrest a person usually suggested that some preliminary field work had been done. In Bykovets's case, this document seems to be designed to demonstrate to the Kyiv NKVD authorities that the local office in Kharkiv was not lethargic. Just the opposite, its staff was alert and active, and was ahead of Kyiv in their decision to unmask another Ukrainian nationalist.

Indeed, Kharkiv NKVD operatives did not waste any time. Bykovets' was arrested on 24 August 1937 by the local NKVD officer Zelem of the NovoSanzharevs'k NKVD sub-department, subordinated to the local Special Department. In the presence of two witnesses, Bykovets's passport and private correspondence were confiscated. Neither manuscripts, nor parts of his catalogue were found during the search of Bykovets's vacation site (AU SBUKh0, spr. 035463, ark. 4).

As mentioned earlier, at the time of his detention Mykhailo was in charge of the Litfond. He assisted Kharkiv writers in receiving grants, vacation funds, housing and the like. His work as a writer and editor appears to have been extremely limited. Marochko and Götz have noted that during the years preceding his arrest Bykovets' lived very quietly, without giving any hint about his existence (74). He engaged in purely organizational matters of the Union of Writers, taking up rather innocent issues, such as financial assistance to writers and their recreation. But apparently, Bykovets's post, as well as his research on Ukrainian history and culture, made him quite important in the eyes of the NKVD in Kyiv.

By order of Kharkiv NKVD officers-namely, the operative of the 3rd Department, Kohan, the head of the 3rd Department, Fisher, and the deputy chief of the NKVD Administration in Kharkiv oblast, Reihman-Bykovets' was convoyed to Kyiv, to the Luk"ianivs'ka prison for preliminary investigation. Only on 13 September 1937 did the Military Prosecutor of the Kyiv Military District, Dubelyr, sign documents for Bykovets's arrest for spying on behalf of a foreign intelligence service (AU SBUKhO, spr. 035463, ark. 7). In other words, the writer had been held for three weeks illegally, as the Kyiv office completely ignored the semi-legal 19 August order by the Kharkiv NKVD to arrest Bykovets'.

The interrogation methods employed by the Kyiv NKVD team proved to be effective. Two weeks after his arrest Bykovets' admitted that he was a conscious Ukrainian nationalist, and individuals such as Vynnychenko, Hrushevs'kyi, and Iefremov shaped his nationalist views. The authenticity of Bykovets's confession is doubtful: it was written in poor Russian, and several 
errors were made in various names, including Serhii Iefremov's (AU SBUKhO, spr. 035463, ark. 11). It is also difficult to imagine that Mykhailo voluntarily identified the pernicious influences of his neighbours in Budynok "Slovo," the writers Andrii Paniv, Serhii Pylypenko, Ostap Vyshnia, and Volodymyr Sosiura who had "discredited" themselves by bourgeois works that were already banned by this time. Most writers had long been arrested (only Sosiura escaped this fate spending a great deal of time in a psychiatric clinic). Moreover, Bykovets' allegedly claimed that he was recruited to a counterrevolutionary nationalist organization by Ostap Vyshnia. Bykovets's confession contains a dialogue between the two writers, which seems to be uncharacteristic of the uniquely personal and individual literary styles of both Bykovets' and Vyshnia:

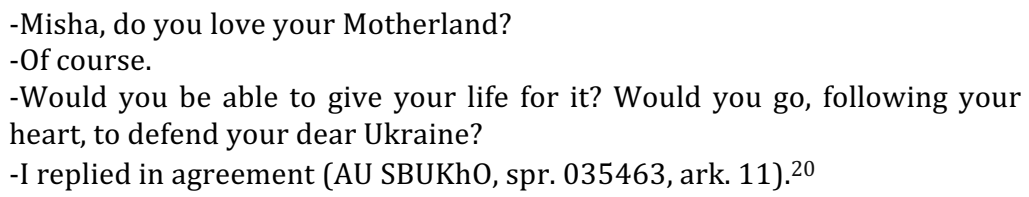

Bykovets's confession was written by hand. Unfortunately, today there are no samples of his handwriting, which makes a graphological analysis unlikely. Bykovets' signed every single page of his confession and interrogation protocols, but the circumstances of his behaviour in prison, as well as his mental and physical condition, remain unknown.

Shterenberg's questions (Bykovets's interrogator) were designed to single out Bykovets's nationalist stance. During the Great Terror, torture as a method employed during preliminary investigation was officially allowed by Moscow and institutionalized. The accused were beaten until they were unconscious. Whatever methods Shterenberg used, they worked. Bykovets' denounced the slov"iany Mykola Kulish, Serhii Pylypenko, Mykola Khvyl'ovyi, Oles' Dosvitnii, Vasyl' Vrazhlyvyi, Valerian Pidmohyl'nyi, Ivan Kalianyk, Ivan Kovtun, Maik Iohansen, Mykola Dukyn, and other individuals (Mykhailo Hylev, Ivan Senchenko, Myroslav Irchan, Maksym Lebid'), identifying them as members of a nationalist organization that worked towards Ukraine's separation from the Union. He also allegedly claimed that the leadership of the organization constantly recruited new members among young writers and "pushed" nationalist ideas through Ukrainian newspapers and

\footnotetext{
20 The dialogue in Russian as it appears in the criminal file:

-Миша, любите ли Вы свой край?

-Конечно.

-А жизнь отдадите за него? Пойдёте ли Вы по зову сердца за родную Украину?

-Я ответил согласием.
} 
magazines (AU SBUKhO, spr. 035463, ark. 14-19). However, Bykovets' continued, the organization did not limit itself to recruiting new members from only literary circles. The singer Ivan Patorzhyns'kyi, the director and actor of the "Berezil'" theatre, Marian Krushel'nyt'skyi, the actor of the "Berezil'" theatre, Iosyp Hirniak, the composer and singer Kostiantyn Bohuslavs'kyi, and the composer Porfyrii Batiuk were also among the members of the criminal group. The name of the famous film director Oleksandr Dovzhenko, a former slov"ianyn, also became part of the plot. Dovzhenko's nationalist views and ideas supposedly inspired the members of the organization and oriented them towards the idea of Ukraine's political and cultural independence (AU SBUKhO, spr. 035463, ark. 19-20). ${ }^{21}$

For those who studied criminal files of the Stalin era, the phrase that usually concludes the first interrogation protocol of the accused sounds amazingly familiar: "During our future meetings, I will tell everything that I know about the organization." 22 This statement, allegedly uttered by the accused, usually set the stage for his/her further revelations about the nationalist conspiracy. Bykovets's deposition confirms this rule. As the case progressed, more and more names of the Ukrainian intelligentsia, "members of the nationalist organization," appeared on the pages of this file. At times in a very creative, skillful manner, and at times in a very bizarre and awkward manner, a complex multilayered scenario of conspiracy united practically all the leading figures of culture and art in Ukraine who worked in the 1930s. Significantly, even during the Great Terror, when the party proclaimed its victory over Ukrainian nationalism, the vector of repression preserved its national element (Shapoval 2009b, 19). The shadow of Ukrainian nationalists haunted NKVD operatives; they were still around and planned to "tear Ukraine from the Union." Written into the script of conspiracy, Ukraine's intellectuals, without regard to their ethnic origin, conspired against the state, and as such, they were immortalized on the pages of almost all individual and group criminal cases dated from 1936 to 1938.

Shterenberg previously had extensive experience investigating cases of Ukrainian intellectuals and peasants who were members of various

\footnotetext{
21 Interestingly enough, the NKVD craftsman, Bykovets's interrogator, wrote Ivan Patorzhyns'kyi into the conspiracy script being unaware of Stalin's favorable attitude toward Patorzhyns'kyi. Patorzhyns'kyi joined the ranks of enemies, Ukrainian nationalists, at least on paper, but he was never repressed. He even visited the United States and Canada after the war in 1946 as a member of the Ukrainian delegation of cultural figures (Kryzhanivs'kyi 58).

22 In Russian: “В дальнейшем я расскажу следствию всё, что мне известно об организации.”
} 
nationalist organizations. ${ }^{23}$ Another prominent theme that Shterenberg focused on when investigating Bykovets's crimes was collectivization and the famine of 1932-33 in Ukraine. Notably, it seems as if Bykovets' himself touched upon the topic, condemning the Party's course of collectivization in Ukraine. He supposedly referred to his conversation with Vyshnia that occurred in April or May 1930 in Budynok "Slovo." Bykovets' allegedly told Vyshnia that Ukraine should not follow this disastrous pathway because soon all Ukrainian villages would be destroyed. In a burst of candor, Bykovets' reminded Vyshnia about the absolutely helpless position of the Ukrainian intelligentsia. From Bykovets's deposition we also learn that Vyshnia supposedly argued that Moscow had always tried to suppress Ukrainian culture, emphasizing that Russian culture, generally speaking, had been always "alien to us" (AU SBUKh0, spr. 035463, ark. 27-28). The level of textual, conceptual, and linguistic primitivism reaches absurd proportions in Bykovets's confession. Its banality and intellectual uniformity sow suspicion about Bykovets's authorship. The conversation of the two gifted writers who possessed witty and analytical minds, was constructed (apparently by Shterenberg) as a sketch, a caricature that made no attempt to mimic the main features of the protagonists.

An interesting "principle of escalation" can be traced in almost all criminal files of those accused of membership in various Ukrainian nationalist organizations. ${ }^{24}$ The interrogation narrative works towards a crescendo, engaging more and more people in the plot who were allegedly active actors in the proposed conspiracy. Bykovets's confession follows the same principle, gradually revealing the essence and the goals of the organization, which supposedly operated in all spheres of Ukraine's cultural life. For instance, the "Berezil'" theatre was corrupt and contaminated through the members' propaganda. According to Bykovets', Maksym Lebid' maintained close operational ties with Les' Kurbas and Iosyp Hirniak in "Berezil'," and Bykovets' himself, with Ostap Vyshnia's assistance, took a secretarial position in the literary association VUSPP for espionage purposes (AU SBUKh0, spr. 035463, ark. 30). The tentacles of the organization reached every single union, association, or state institution, which were allegedly transformed into nationalist underground cells that were ready to act at any moment.

\footnotetext{
${ }^{23}$ Shterenberg's name appears in several sources: HDA SBU, spr. 31308fp; Holodomor 1932-33 rokiv $v$ Ukraini za dokumentamy HDA SBU <http://history.org.ua/ LiberUA/978-966-1594-17-2/5.pdf>; Petrovs'kyi 380-88; Koval' 2005.

${ }^{24}$ From 2007 to 2015 , approximately 2,000 criminal files located in various Ukrainian archives have been studied by this author.
} 
Considering the uniformity of methodological techniques that the investigators employed during preliminary investigations, it is no surprise that the same themes and questions emerged over and over again during the interrogation of many different people. One of the typical themes was the involvement of Galicians in nationalist organizations and in the activities of Ukrainian nationalist circles abroad. ${ }^{25}$ The majority of the accused confessed to their close relationships with Galician intellectuals who came from Poland and elsewhere to contribute to Ukrainization. The name of Myroslav Irchan (Ukrainian writer, historian and journalist) was exploited quite regularly by NKVD operatives. Bykovets' also confessed that through Vyshnia and Lebid' he established contacts with Irchan, Stepan Rudyk (Ukrainian politician and journalist), Mykola Holubets' (poet and art critic from Lviv) and the staff of journals such as Kul'tura (Culture) and Nova kul'tura (New Culture) and, with their help, conducted subversive work in Soviet Ukraine. Bykovets' further revealed that the representatives of the Ukrainian National Democratic Alliance (UNDO) in Galicia also participated in their organization, and even its leadership sent their agent Vasyl' Bobyns'kyi (Ukrainian poet) to Soviet Ukraine for intelligence purposes. Moreover, before his arrest Vasyl' Atamaniuk (writer and political activist) allegedly informed Bykovets' that on 1 May 1932 they were prepared to overthrow the government in Ukraine. Shterenberg, of course, was aware of the arrests of most Galicians in the early-mid thirties. After their arrest, the links among Galicians in Poland and the intelligentsia in Soviet Ukraine were disrupted. But for the record, in order to demonstrate the vitality of Ukrainian nationalism, Ivan Senchenko was written into the script of conspiracy. He became a new connection, a person who was responsible for communications with the UNDO, at least according to Shterenberg's account signed by Bykovets' (AU SBUKhO, spr. 035463, ark. 31-34).

The NKVD took less than two months to finalize Bykovets's case from the day of his arrest to the day of his verdict, and it was approved by the People's Commissar of Internal Affairs of the USSR Izrail' Leplevskii and the General Prosecutor of the USSR Andrei Vyshinskii on 22 October 1937. Bykovets' was interrogated three times: on 11 September, 3 October, and 17 October 1937. This proved to be sufficient to sentence him to death and to execute him immediately, a day following the verdict. During his last interrogation on 17 October, Shterenberg made sure that Bykovets' identified more names of those who allegedly worked for the organization. This would provide the evidential base for future arrests. Those who were already in prison and those who were still at large were put on the list. Among them were the

${ }^{25}$ For a discussion about the repression of Galicians in Ukraine, see Bertelsen and Shkandrij 37-62. 
Ukrainian writers and the slov"iany Volodymyr Gzhyts'kyi, Hryhorii Epik, Volodymyr Sosiura, Ievhen Kas'ianenko, Volodymyr Dukyn, Petro Panch, Ivan Kulyk, Ivan Mykytenko, Oleksandr Dovzhenko, Ivan Kalianyk, Ivan Shutov, and Ivan Tkachuk. According to the interrogation protocol, they participated in preparing terrorist acts against members of the government (AU SBUKhO, spr. 035463, ark. 36-49).

The name of the Ukrainian politician and diplomat Naum Kaliuzhnyi also found its place in the last interrogation protocol. Kaliuzhnyi allegedly worked closely with like-minded writers, such as Tychyna, Kulyk, and Mykytenko and, as the protocol says, Bykovets' had evidence which fully exposed them as counterrevolutionaries: their correspondence. This deposition became grounds for the arrest of Kaliuzhnyi, who in March 1937 resigned from his post as the People's Commissar of Justice in the UkrSSR due to illness. On 18 September 1937 he was arrested in Kharkiv as a member of the Ukrainian Military Organization (UVO) (Mushynka 1991; Rubl'ov, and Cherchenko 1994; Surovtseva 1996; Rubl'ov and Synyts'kyi 2007).

As the materials of Bykovets's criminal case reveal, Bykovets' was denounced by the writer Mykhailo Ialovyi, the head of the Publishing House "Rukh" (Movement) and the editing board of the Ukrainian Soviet Encyclopedia Anton Bilen'kyi-Berezyns'kyi, the historian and writer Mykola Horban', and the writer Hryhorii Epik. Bykovets's name was also mentioned in the criminal file of a "participant of a counterrevolutionary organization," the slov"ianyn Andrii Paniv, and in the multi-volume file of Mykola Zerov and other "nationalists." Ultimately, his fate was predetermined since 19341935, and it was a matter of time before Bykovets' himself appeared before the investigators in 1937 as a veiled enemy: a counterrevolutionary, a terrorist, a former Petliurite, and an active member of the Ukrainian nationalist organization engaged in training rebel groups in the countryside against the Soviet regime, and in terrorist acts against the leaders of the party and the government (AU SBUKhO, spr. 035463, ark. 61-75; HDA SBU, spr. $48570 \mathrm{fp})^{26}$

According to the conclusion of the prosecution (vysnovok obvynuvachennia), in order to hide counterrevolutionary activities of the members of his organizations, in 1933 Bykovets', acting on Vyshnia's and Senchenko's instructions, allegedly destroyed archival documents of the literary association VAPLITE. In addition, in 1937 he supposedly destroyed papers related to the journal Chervonyi shliakh (AU SBUKhO, spr. 035463, ark. 74). There are, however, several inconsistencies in this conclusion. For instance, in February 1936, the journal Chervonyi shliakh was liquidated as a

${ }^{26}$ See also the text of the 3 January 1935 interrogation protocol of Andrii Paniv in Dukyna 134-35. 
counterrevolutionary publication, together with its authors, editors, and documentation. Prior to that, on 14 January 1928, VAPLITE had ceased its existence because of pressure from the party. ${ }^{27}$ This resulted in the confiscation of an entire issue of the journal VAPLITE that contained the second part of the "ideologically harmful" novel Val'dshnepy (Woodcocks), written by Khvyl'ovyi. But Bykovets' had never been a member of VAPLITE. Moreover, an alleged conspiracy among Bykovets', Vyshnia and Senchenko seems extremely problematic because by August 1937 Vyshnia already had been imprisoned for several years, and Senchenko, the alleged "henchman and member of a nationalist organization hostile to the Soviet government," had never been touched by the secret organs. Nonetheless, these discrepancies and inconsistencies were apparently minor details for the prosecutor who ignored them altogether while deciding on his verdict. Bykovets's confession was paramount to the prosecutor who sentenced him to death.

According to records of the 23 October 1937 closed-court session of the Military Collegium of the Supreme Court, Bykovets' was in the courtroom during the hearing of his case. His request to call witnesses during the hearing was denied. Bykovets' fully admitted his guilt. He confirmed his testimonies given during the preliminary investigation, and expressed no desire for a new trial with new court members. The only request Bykovets' expressed in court was to save his life: he promised to be useful to society. However, in accordance with the 1 December 1934 resolution of the Central Executive Committee of the USSR, Bykovets' was sentenced to be shot immediately. All his property was to be confiscated. The sentence was carried out the next day on 24 October 1937 in Kyiv, which was certified and signed by Shevel'ov, head of the $12^{\text {th }}$ sub-department of the NKVD Special Department of the USSR (AU SBUKhO, spr. 035463, ark. 77-80).

The documents of the rehabilitation commission, which began to reexamine Bykovets's case only in 1989 nearly half a century after his death, reveal that the first wave of rehabilitations during the Khrushchev thaw found all people who were mentioned in Bykovets's case not guilty, those who, through physical and moral abuse, denounced Bykovets' and those who were denounced by him. Unfortunately, Bykovets' had no family at the time of his detention, which may have helped shed some light on his behaviour during the last two months of his life in prison, as happened in the cases of Volodymyr Gzhyts'kyi, Ostap Vyshnia, Oles' Dosvitnii, Serhii Pylypenko, Marko Voronyi, Onanii Lebid', and many other Ukrainian writers (HDA SBU, spr. 48570 fp, t. 6; spr. 36546 fp, t. 11; TsDAHOU, spr. 263, op.1, spr. 44228,

27 See the 14 January 1928 resolution of VAPLITE's meeting in Kostiuk 681-82. 
t.1-2). On 28 December 1992 the former Deputy General Prosecutor of Ukraine, Iurii Haisyns'kyi, confirmed that the SBU was unable to find Bykovets's relatives. On 18 June 1993, the SBU also informed the State Archive of Kharkiv Oblast (DAKhO) that Bykovets's burial place was unknown (AU SBUKh0, spr. 035463, ark. 136, 139). Quite possibly, due to some linguistic and symbolic coincidence, Bykovets' was buried in Bykivnia near Kyiv: in 1937 the NKVD dumped many bodies of those who were shot in the Luk"ianivs'ka prison in Bykivnia. ${ }^{28}$

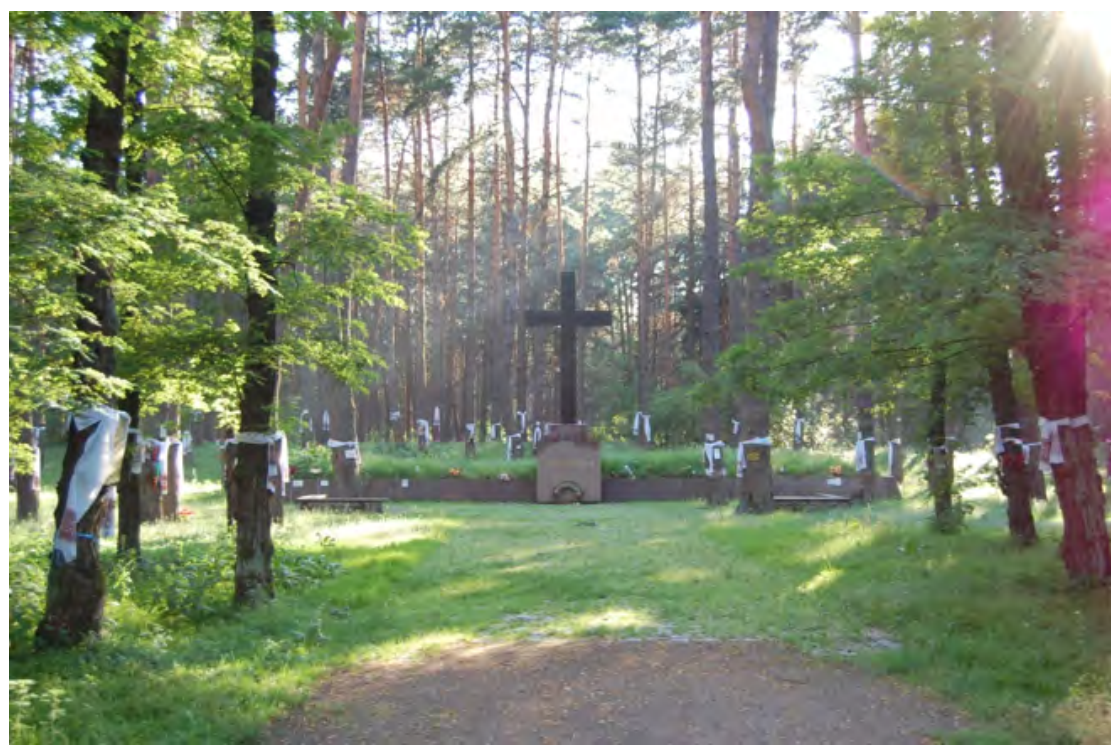

Fig. 10. The National Park "Bykivnians'ki mohyly."

As mentioned earlier, the wave of terror in the early 1930s swallowed most of the slov"iany and most intellectuals in Ukraine throughout the country. Bykovets' happened to live a few years longer than his neighbours, enjoying freedom and his beautiful apartment in Budynok "Slovo." In 19371938, along with Bykovets', the rest of the slov"iany went to the cellars of the NKVD, and eventually into oblivion that lasted at least 50 years (Dukyna 13646). Among them were Mykhail' Semenko, Ivan Kulyk, Liutsiana Piontek, Maik Iohansen, Volodymyr Koriak, Ievhen Kas'ianenko, Antin Dykyi, Ivan Kyrylenko, Hryhorii Kotsiuba, and Volodymyr Dukyn. Ivan Mykytenko allegedly committed suicide. Did Bykovets' perceive himself as a "participant

${ }^{28}$ For a discussion about Bykivnia, see Carynnyk 183; Kuromiya 20-24; Amons 2007. For Bykivnia's historiography and sources, see Bilokin' 801-76. 
in life," according to his own definition, in the stifling atmosphere of Budynok "Slovo," which the writers secretly referred to as BUPR, the building of preliminary imprisonment (Sokil 84, 103, 106, 110-11)? In the courtyard of the building, two young men in similar civilian clothes were on duty day and night, watching the inhabitants. Perhaps, Bykovets' dreamed of a quiet life in Kaniv, near the monument to the great Kobzar, where in winter there were blizzards, and people went down the steep hill to the Dnipro River to get some water, as the old man Ivan did.

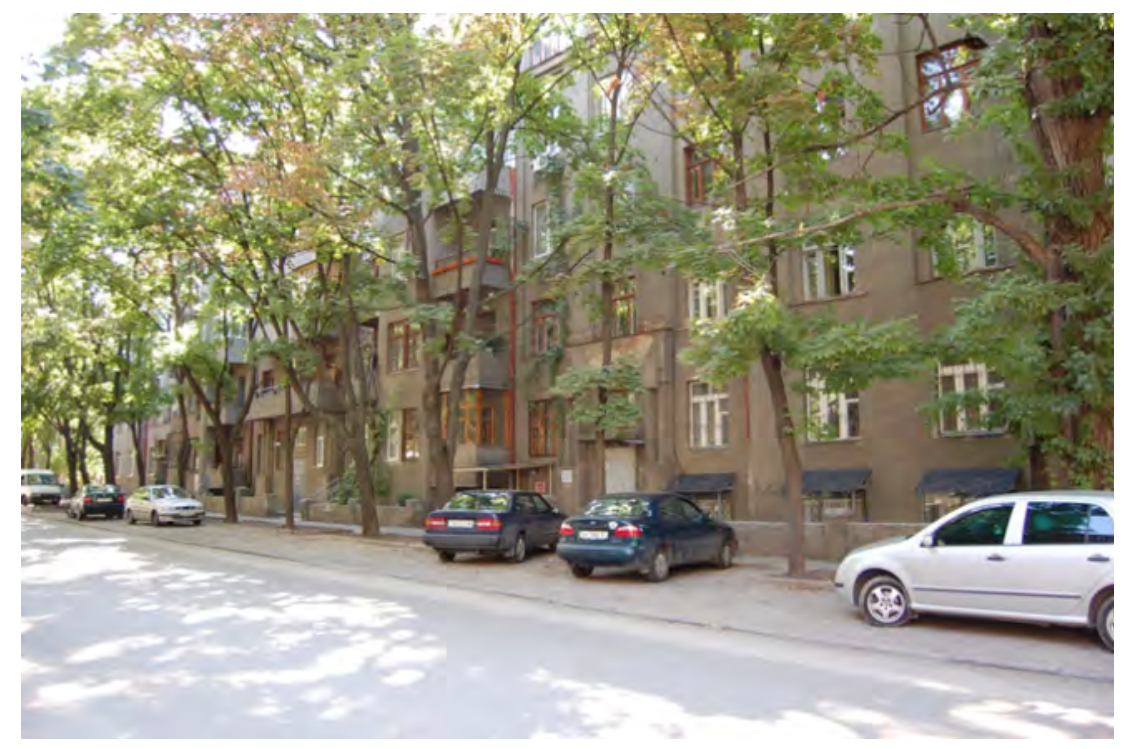

Fig. 11. Budynok "Slovo" today (Kharkiv).

\section{EPILOGUE}

Perhaps Bykovets' was not an outstanding writer, but he cherished Ukrainian national traditions and belonged to the conscious Ukrainian intelligentsia, whose activities contributed greatly to the preservation and dissemination of Ukrainian culture. Bykovets' spent his last birthday, 3 September, in a prison cell, and his life was terminated when he was 43 years old. He was nearly as old as his literary mentor Serhii Pylypenko at the time of his death.

There should be little doubt about why Bykovets' and his colleagues were accused of Ukrainian nationalism, and why the NKVD considered someone a Ukrainian nationalist. Iurii Shevel'ov offered an instructive suggestion that "the NKVD considered [any] teacher a Ukrainian nationalist 
who, having completed a lecture in the Ukrainian language, continued to speak Ukrainian with his students after the lecture" (Shevel'ov 779). Bykovets' perfectly fit this description but he was not a member of any nationalist organization, and archival documents recently discovered in various sectoral SBU and Ukrainian state archives demonstrate that the cases that were given special code names by GPU/NKVD operatives, such as OUN, UVO and others, were fabricated by the secret police (Shkandrij and Bertelsen 2013). He was an active participant of Ukrainization, and he, like many other Ukrainian writers, was committed to the nation-building project. George 0. Liber has aptly noted that "unlike Russian writers, who were committed to Bolshevik state-building in the 1920s, Ukrainian writers were involved in nation-building" (Liber 123). The Ukrainians strove to build a national culture and were not only forbidden to do so, but also punished through repression and execution. Individual histories of the slov"iany reveal that the intelligentsia in Ukraine was not an "ambiguously privileged group within society," as Sheila Fitzpatrick has argued (Fitzpatrick 245). Although Fitzpatrick's supposition might be true for the RSFSR, by 1933, the Ukrainian intelligentsia was not only not a privileged group, it was virtually destroyed-thousands of people were exiled and executed through individual and group criminal cases and show trials by 1934. The Great Terror cleansed the rest, those who were considered politically unreliable and nationally oriented.

Indeed, for most Ukrainian intellectuals the meaning of their lives was derived not from the state as a vehicle of the revolutionary project, but from the regional, national, and cultural landscape. In other words, they were more nationally oriented than revolutionary, although they all emerged from the Revolution, understandings of which differed in Russia and Ukraine. They were inspired by Ukrainization policies that were reversed in 1926. The revolutionary project for them was the de-Russification of Ukraine, which the state perceived as a threat to its cohesiveness and centralization. Those few who were still free by 1937 were questioned by the NKVD about their revolutionary project, and in the frenzy of mass killings the state did not take the risk of re-educating them.

With very few sources, which also include the falsified criminal file (an unclear history of imprisonment and the ultimate execution of the writer that this study attempted to reconstruct), it is very difficult to understand Bykovets' as a poet and a writer who lived almost eighty years ago. His literary legacy is extensive but it has not been systematically collected or published yet. His creative work is characterized by socialist optimism, an element typical of the time. One might experience difficulty discerning the true thoughts and feelings in some of Bykovets's work. His experience as a bureaucrat who held public office often determined Bykovets's formal and 
provincial literary style. Tragedy as a literary genre or tragedy as self- and world-perception through which readers can better understand writers ceased to exist in the bloody 1930s: this genre lost its meaning and made no sense during the time of construction of a new communist society.

Bykovets's private archive and his unique catalogue, which could be an invaluable source for a deeper analysis of his creative art disappeared in the whirlpool of the Great Terror. Iurii Smolych remembered that before the Nazis took Kharkiv on 24 October 1941, in the inside yard of the NKVD's headquarters in Sovnarkomivs'ka Street, the agency had been burning for several days documents, books, diaries and manuscripts confiscated during searches. Kharkiv's central streets were covered with black charred paper ashes (Smolych 144). Possibly, Bykovets's archive also ended up in this Goebbels-like bonfire. Nevertheless, we may always hope that one day a scholar might discover his lost catalogue, as Hryhorii Kostiuk always hoped that someone might find the continuation of Khvyl'ovyi's Val'dshnepy.

In the 1930s, Ukraine experienced tremendous cultural disruption due to Stalin's terror, a tragedy that somewhat explains the current pernicious trends in contemporary Ukrainian society and its ability to preserve, develop, and protect its cultural and national traditions. Is this historical legacy a negative condition for the nation-building project? Shevel'ov once wrote:

The flourishing of art is not necessarily and directly connected with the state and nation building. However, one cannot further argue that no connection exists between these two processes. ${ }^{29}$

The interconnectedness of the cultural and nation-building projects emphasized by Shevel'ov becomes even more obvious when it is discussed in the context of the enormous human losses and cultural disruption in Ukraine caused by Stalin's terror, and is also evident today, when Ukraine struggles for its sovereignty, independence, and survival. The history of Budynok "Slovo" in general, and Bykovets's individual history in particular, help us better understand not only those who were eliminated by the Soviet regime in the 1930s but also those who were disillusioned in the 1960s and the 1970s, and those who are disheartened today.

\footnotetext{
29 In Ukrainian: “Розквіт мистецтва не стоїть у прямому і обов’язковому зв’язку 3 побудуванням національної держави. Але не можна твердити i протилежного-що жадного зв'язку між цими двома рядами подій взагалі нема."
} 


\section{Works Cited}

Amons, A. I., ed. Bukivnians'ki zhertvy abo Iak pratsiuvala "Vyshcha dviika" na Kyivshchyni: Dokumenty ta materialy. Kyiv: MAUP, 2007. Print.

Arnautov, V. O. "Korotkyi narys istorii sotsial'noho vykhovannia na Ukraini." Zapysky kharkivskoho instytutu narodnoi osvity im. O. O. Potebni 2 (1927): 3-17. Print.

Bertelsen, Olga. "The House of Writers in Ukraine, the 1930s: Conceived, Lived, Perceived." Carl Beck Papers 2302 (August 2013): 4-72. Print.

Bertelsen, Olga, and Myroslav Shkandrij. "The Secret Police and the Campaign against Galicians in Soviet Ukraine, 1929-34." Nationalities Papers: The Journal of Nationalism and Ethnicity 42.1 (2014): 37-62. Print.

Bilokin', Serhii. Masovyi teror iak zasib derzhavnoho upravlinnia v SRSR (1917-1941 rr.): Dzhereloznavche doslidzhennia. Vol. 2. Drohobych: Kolo, 2013. Print.

Borchuk, Stepan. Ukrains'ka entsyklopedychna tradytsiia XX st.: Proekty, vykonavtsi, perspektyvy doslidzhennia. Diss. Pereiaslav-Khmel'nyts'kyi Derzhavnyi Pedahohichnyi Universytet imeni Hryhoriia Skovorody, 2015. Print.

Marusyk, Mykh. "Narada v spravi krytyky i bibliohrafii." Pluzhanyn 2 (1925): 17. Print. Byk, Mykh. "V Ts.K. 'Pluha.'” Pluzhanyn 2 (1925): 30. Print.

Bykovets', M., ed. Otak to teper: zbirka p"ies i estradnoho materialu do vesnianoi zasivnoi kampanii ta kolektyvizatsii. Kharkiv: Rukh, 1930. Print.

Bykovets', M. "Potochni notatky: na mohyli T. Shevchenka." Pluzhanyn 5 (1927): 3234. Print.

Carynnyk, Marco. “Bykivnia. I — zhodnoho obvynuvachenoho.” Vsesvit 10 (1992): 182-87. Print.

Chervoni kvity 1 (1923). Print.

Chervonyi shliakh 7 (1928). Print.

Chervonyi shliakh 5-6 (1929). Print.

Conquest, Robert. The Great Terror: A Reassessment. New York: Oxford UP, 1990. Print.

---. The Great Terror: Stalin's Purge of the Thirties. Toronto: The Macmillan Company, 1969. Print.

Danylenko, Vasyl', ed. Ukrains'ka intelihentsiia $i$ vlada: Zvedennia sekretnoho viddilu DPU USRR 1927-1929 rr. Kyiv: Tempora, 2012. Print.

Dukyna, Natalka. Na dobryi spomyn: povist' pro bat'ka. Kharkiv: Vydannia zhurnalu "Berezil'," 2002. Print.

Dzeverina, I. O. et al. Ukrains'ka Literaturna Entsyklopedia. Vol. 1. Kyiv: Holovna redaktsiia Ukrains'koi Radians'koi Entsyklopedii im. M. P. Bazhana, 1988. Print.

Dziuba, Ivan. Z krynytsi lit. Vol. 1. Kyiv: Vydavnychyi dim “KMA,” 2006. Print.

Fitzpatrick, Sheila. The Cultural Front: Power and Culture in Revolutionary Russia. Ithaca and London: Cornell UP, 1992. Print.

Halfin, Igal. Terror in My Soul: Communist Autobiographies on Trial. Cambridge, Massachusetts: Cambridge UP, 2003. Print.

Hellbeck, Jochen. Revolution on My Mind: Writing a Diary Under Stalin. Cambridge: Harvard UP, 2006. Print.

Hodkevych, M. “Ukrains'ke pys'menstvo za 10 lit.” Pluzhanyn 11-12 (1927): 58-65. Print. 
Hrechaniuk, Serhii. "Volodymyr Vynnychenko: povernennia." Radians'ke literaturoznavstvo 8 (1989): 68-72. Print.

Iakovenko, Hryhorii. "Pro krytykiv i krytyku v literaturi." Kul'tura i pobut 17 (1925): 4. Print.

Iefremov, Serhii. Shchodennyky, 1923-1929. Ed. O. I. Putro et al. Kyiv: Hazeta Rada, 1997. Print.

Khlevniuk, Oleg V. Master of the House: Stalin and His Inner Circle. Trans. Nora Seligman Favorov. New Haven and London: Yale UP, 2009. Print.

Kostiuk, Hryhorii, ed. Tvory v p"iat'okh tomakh Mykoly Khvyl'ovoho. Vol. 5. New York and Baltimore: Smoloskyp, 1986. Print.

Koval', Roman. "Nevyhadani istorii: Spohady chekista Ptashyns'koho." Za voliu $i$ chest': Nevyhadani istoii i voiats'ki biohrafii. Web Ukrains'ke zhyttia v Sevastopoli. Web. 14 Jan. 2016. <http://ukrlife.org/main/evshan/za_volyu5.htm>.

Kryzhanivs'kyi, Stepan. My piznavaly nepovtornyi chas: Portrety, ese, spohady. Kyiv: Radians'kyi pysmennyk, 1986. Print.

Kul'tura i pobut, dodatok do Visti VUTsVK, 30 April 1925. Print.

Kuromiya, Hiroaki. The Voices of the Dead: Stalin's Great Terror in the 1930s. New Haven and London: Yale UP, 2007. Print.

Liashko, Svitlana. "Z istorii ukrains'koi biohrafichnoi dovidkovoi spravy: biohrafichni dovidkovi i dovidkovi vydannia 1920-1930-kh rr., iaki ne pobachyly svitu." Naukovi pratsi Natsional'noi biblioteky Ukrainy imeni V. I. Vernads'koho 37 (2013): 584-86. Print.

Liber, George O. Soviet Nationality Policy, Urban Growth, and Identity Change in the Ukrainian SSR, 1923-1934. New York: Cambridge UP, 1992. Print.

Literaturnomu fondu SSSR 125 let. Moskva: Vneshtorgizdat, Izd. no. K1297, 1984. Print.

Luckyj, George S.N. Literary Politics in the Soviet Ukraine, 1917-1934. Durham and London: Duke UP, 1990. Print.

Marchenko, M., and M. Bykovets', eds. Selians'kyi kalendar na 1928 rik. Kharkiv: Vydavnytstvo Vseukrains'koi selians'koi hazety "Radianske selo," 1928. Print.

Marochko, Vasyl', and Hillig Götz. Represovani pedahohy Ukrainy: Zhertvy politychnoho teroru (1929-1941). Kyiv: Vydavnytstvo "Naukovyi svit," 2003. Print.

Mushynka, M., ed. Lysty Stepana Rudnyts'koho do Sofii ta Stanyslava Dnistrians'kykh (1926-1932). Edmonton: Canadian Institute of Ukrainian Studies, 1991. Print.

Nevira, Khar'ko. "Literatura chy sazh?” Pluzhanyn 1 (1926): 18. Print.

---. "Potochni notatky: Shche raz pro Mykolu Khvyl'ovoho." Pluzhanyn 4 (1927): 23. Print.

Orlov, Iurii. Nebezpechni dumky: Memuary z rosiis'koho zhyttia. Trans. P. Romko. Kyiv: Smoloskyp, 2012. Print.

Panchenko, Vladimir. "Marksist, kotoryi khotel ostat'sia ukraintsem." Ed. L. Ivshyna. Kyiv: Ukrainskaia press-gruppa, 2004. Print.

Petrovs'kyi, I. P. "Ivan Petrovych Pohorilyi (1899-1937): Trahichna dolia kerivnyka kafedry istorii Ukrainy Odes'koho universytetu." Problemy istorii Ukrainy: Fakty, sudzhennia, poshuky. Kyiv: Instytut istorii Ukrainy NAN Ukrainy 12 (2004): 38088. Print. 
P"iadyk, Iurii. Ukrains'ka poeziia kintsia XIX-seredyny XX st.: Bibliohrafiia. Antolohiia. Vol. I Kyiv: K.I.S., 2010. Print.

Rubl'ov, Oleksandr, and Mykhailo Fel'baba. "Doli spivrobitnykiv 'URE' na tli represyvnoi polityky 30-kh rokiv." Security Service in Ukraine. Web. 11 Oct. 2015. <http://www.ssu.gov.ua/sbu/doccatalog\%5Cdocument?id=42136>.

Rubl'ov, 0. S., and I. A. Cherchenko. Stalinshchyna i dolia zakhidnoukrains'koi intelihentsii: 20-50-ti rr. XX st. Kyiv: Naukova dumka, 1994. Print.

Rubl'ov, O. S., and P. I. Synyts'kyi. "Do istorii vitchyznianoho sovetofil'stva pochatku 1920-kh rokiv: spivrobitnytstvo N. Surovtsevoi u chasopysi 'Nova hromada'." Problemy istorii Ukrainy 19-poch. 20 st. 13 (2007): 197-219. Print.

Savchenko, I. Deshcho z istorii mohyly Shevchenka. Kharkiv: Instytut T. Shevchenka, DVU, 1930. Print.

Senchenko, Ivan. "Notatky pro literaturne zhyttia 20-40 rokiv." Opovidannia. Povisti. Spohady. Kyiv: Naukova dumka, 1990. 540-79. Print. Also available at <http://www.ukrcenter.com>.

Shapoval, Iurii. "Fatal'na ambivalentnist." Poliuvannia na Val'dshnepa: Rozsekrechenyi Mykola Khvyl'ovyi. Ed. I. Shapoval. Kyiv: Tempora, 2009. Print.

---. “'Velykyi teror' v Ukraini: etapy, osoblyvosti, naslidky." Ukraina v dobu 'Velykoho teroru': 1936-1938 roky. Eds. Serhii Bohunov et al. Kyiv: Lybid', 2009. Print.

Shapoval, Iurii, and Vadym Zolotar'ov. Vsevolod Balyts'kyi: Osoba, chas, otochennia. Kyiv: Stylos, 2002. Print.

Shapoval, Iurii, Volodymyr Prystaiko, and Vadym Zolotar'ov. ChK-GPU-NKVD $v$ Ukraini: osoby, fakty, dokumenty. Kyiv: Abrys, 1997. Print.

Shepeliuk, V. "Z kohorty prosvitian." Literaturna Ukraina 25 August 2011, late ed.:13+. Print.

Shevel'ov, Iurii. Vybrani pratsi: Literaturoznavstvo. Ed. I. Dziuba. Vol. 2. Kyiv: Vydavnytstvo "KMA," 2008. Print.

Shkandrij, Myroslav. Modernists, Marxists and the Nation: The Ukrainian Literary Discussion of the 1920s. Edmonton: Canadian Institute of Ukrainian Studies Press, University of Alberta, 1992. Print.

Shkandrij, Myroslav, and Olga Bertelsen. "The Soviet Regime's National Operations in Ukraine, 1929-1934." Canadian Slavonic Papers LV.3-4 (2013): 417-47. Print.

Smolych, Iurii. Rozpovid' pro nespokii tryvae: deshcho z dvadtsiatykh, trydtsiatykh rokiv i doteper v ukrains'komu literaturnomu pobuti. Vol. 2. Kyiv: Radians'kyi pys'mennyk, 1969. Print.

Snehir'ov, Helii. Naboi dlia rozstrilu ta inshi tvory. New York: Vydannia Hromads'koho Komitetu i Novykh Dniv, 1983. Print.

Sokil, Vasyl'. Zdaleka do blyz'koho (spohady, rozdumy). Edmonton: Kanads'kyi instytut ukrains'kykh studii, Alberts'kyi universytet, 1987. Print.

Stalin, I. Sochineniia. Vol. 8. Moskva: Institut Marksa-Engel'sa-Lenina pri TsK VKP(b), 1948. Print.

Surovtseva, Nadiia. Spohady. Kyiv: Vydavnytstvo im. O. Telihy, 1996. Print.

Tsymbal, Iaryna. "Istoriia VAPLITE u 3D." Spadshchyna: Literaturne dzhereloznavstvo. Tekstolohiia VII. Kyiv: Instytut literatury im. T.H. Shevchenka NAN Ukrainy; Laurus, 2012. Print.

Vatulescu, Cristina. Police Aesthetics: Literature, Film, and the Secret Police in Soviet Times. Stanford: Stanford UP, 2010. Print. 
Weiss, Michael. "Inhuman Power of the Lie: 'The Great Terror at 40." The New Criterion February (2008): 17-24. Print.

Zabuzhko, Oksana. Khroniky vid Fortinbrasa: Vybrana eseistyka. Kyiv: Vydavnytstvo "Fakt," 2006. Print.

Zerov, Mykola. "U spravi virshovanoho perekladu." Zhyttia i revoliutsiia IX (1928): 133-46. Print.

Znannia 2-3 (1925). Print.

Zolotar'ov, Vadym. "Nachal'nyts'kyi sklad NKVS USRR naperedodni 'ezhovshchyny:' sotsial'no-statystychnyi analiz." Ukraina $v$ dobu 'Velykoho teroru': 1936-1938 roky. Eds. Serhii Bohunov et al. Kyiv: Lybid', 2009. 60-83. Print.

Sekretno-politychnyi viddil DPU USRR: spavy ta liudy. Kharkiv: Folio, 2007. Print. 
(c) 2016 East/West: Journal of Ukrainian Studies (ewjus.com) ISSN 2292-7956 Volume III, No. 1 (2016) 